\title{
Penggunaan Media Pembelajaran Visual pada Mata Kuliah Estetika
}

\author{
Siti Nurannisaa P.B. ${ }^{1}$, Anny Valentina ${ }^{2}$, Augustina Ika Widyani ${ }^{3}$ \\ Fakultas Seni Rupa dan Desain, Universitas Tarumagara ${ }^{1,2,3}$ \\ sitip@fsrd.untar.ac.id
}

\begin{abstract}
Mahasiswa Baru merupakan calon desainer yang baru mulai belajar desain baik dalam bentuk teori maupun praktik. Pembelajaran pada jurusan desain memiliki pola dan kekhasannya, salah satunya adalah kemampuan dan keberanian dalam mengekspresikan pendapat serta gagasan. Kemampuan ini dibutuhkan dalam setiap mata kuliah ayng akan dijalani. Mata kuliah Estetika, merupakan salah satu mata kuliah yang memiliki bagian dari keilmuan filsafat dan materi nya sebagian bersifat abstrak, diperlukan strategi khusus dalam proses pembelajaran, khususnya agar mudah dimengerti bagi mahasiswa baru. Penelitian ini bertujuan menemukan media pembelajaran yang mampu menstimulasi mahasiswa dalam mempelajari mata kuliah Estetika, sehingga mereka mampu melakukan proses pembelajaran dengan optimal. Media pembelajaran visual dipilih untuk digunakan sebagai strategi dalam mencapai tujuan instruksional perkuliahan. Dengan penerapan media pembelajaran visual, diharapkan memudahkan mahasiswa dalam mempelajari materi perkuliahan yang bersifat teoritis.
\end{abstract}

Kata kunci: media, visual, estetika, pembelajaran

\section{PENDAHULUAN}

Keilmuan seni rupa dan desain merupakan salah satu pilihan bagi para calon pekerja kreatif, salah satunya desainer yang nantinya akan turut mewarnai dunia industri kreatif di Indonesia. Bagi mahasiswa yang baru masuk pada semester awal sekolah desain pada umumnya mereka memerlukan penyesuaian dalam proses belajar mengajar. Protokoler pendidikan yang serba teratur misalnya terbiasa dalam penggunaan seragam sekolah, jadwal masuk sekolah dengan jam yang sama, cara belajar yang sistematis dan teratur sesuai arahan sekolah membuat para siswa baru memerlukan waktu dalam menyesuaikan dirinya dengan pola balajar sebagai mahasiswa. Kemandirian belajar, kebebasan berekspresi, kemampuan menentukan dan mengatur jadwal belajar adalah beberapa hal yang perlu waktu dalam hal pembiasaannya.

Pembelajaran pada jurusan desain memiliki pola dan kekhasannya. Keberanian, kreativitas, daya tahan stamina dalam mengerjakan suatu karya dan kemampuan berpikir kreatif merupakan beberapa modal penting dalam keberhasilan menjalani proses belajar. Untuk mencapai keberhasilan pembelajaran terutama pada semester 1 (satu) di setiap mata kuliah teori di Fakultas Seni Rupa dan Desain Universitas Tarumanagara (FSRD UNTAR), diperlukan upaya khusus bagi pengajar untuk mengenali 
karakter mahasiswanya, sehingga metoda dan media pembelajaran yang yang diterapkan sesuai dengan karakter mahasiswa baru. Pengajar di bidang desain diharapkan juga mampu mengembangkan berbagai bahan ajar, agar secara kreatif dapat menciptakan suasana belajar yang memudahkan mahasiswa baru dalam proses belajar. Penggunaan berbagai ragam media belajar yang sesuai dengan karakteristik mata kuliah diharapkan mampu menumbuhkan motivasi belajar mahasiswa baru.

Media merupakan salah satu faktor penentu keberhasilan pembelajaran. Melalui media, proses pembelajaran bisa lebih menarik dan menyenangkan, misalnya mahasiswa yang memiliki ketertarikan terhadap gambar dapat diberikan berbagai ragam media visual dalam proses belajarnya, begitu juga dengan media-media yang lain seperti audio ataupun kombinasi audio visual seperti video. Media juda diartikan sebagai alat yang dapat membantu proses belajar mengajar yang berfungsi memperjelas makna pesan yang disampaikan sehingga tujuan pengajaran dapat tercapai lebih baik, lebih sempurna (Daryanto, 1993). Media pembelajaran yang dikemas menyenangkan untuk mahasiswa, dapat meningkatkan ketertarikan proses belajarnya melalui ragam media. Penggunaan media juga dapat membantu memperjelas pesan pembelajaran. Informasi yang tidak dapat dipahami oleh siswa, dapat terbantu dengan penggunaan media yang tepat. Dengan demikian peran media sebagai alat bantu sangat memperjelas pesan pembelajaran.

Berdasarkan observasi sebelumnya pada Mata Kuliah Estetika yang ada di FSRD UNTAR tempat dilaksanakan penelitian ini, ditemukan bahwa proses pembelajaran dikelas aktifitas belajarnya cukup baik. Proses belajar secara umum didominasi oleh metode konvensional yaitu ceramah dan tanya jawab. Dalam proses pembelajaran aktivitas dan perhatian mahasiswa pada saat penjelasan materi pelajaran, cenderung pasif. Aktivitas seperti mencetuskan gagasan dan menyelesaikan masalah, bertanya atau pun bertukar pikiran masih sangat kurang. Dengan keadaan tersebut hasil belajar masih cenderung rendah dan ditandai adanya sebagian mahasiswa yang kesulitan dalam memahami materi. Hal ini menyebabkan kemampuan berpikir kreatif yang seharusnya mulai terlatih tidak dapat dioptimalkan saat pembelajaran dikelas.

Mata Kuliah Estetika sebagai mata kuliah teori semester 1 (satu) di Program Studi Interior, juga sering diasumsikan sebagai mata 
kuliah yang sulit dipahami oleh mahasiswa karena merupakan bagian dari ilmu filsafat. Oleh karena itu perlu perencanaan strategi pembelajaran yang sesuai untuk mahasiswa baru agar dapat mencapai Tujuan Instruksional (indikator) dari Mata Kuliah Estetika tersebut. Berdasarkan permasalahan tersebut, penelitian ini dilakukan dengan dalam upaya memperbaiki strategi pembelajaran dengan menerapkan penggunaan media pembelajaran visual, sehingga motivasi dan keaktifan mahasiswa dapat ditingkatkan. Penelitian ini bertujuan untuk membuat perancangan ragam media penyampaian pembelajaran visual, sebagai bagian dari pengembangan strategi pengajaran yang sesuai bagi mahasiswa baru di mata kuliah Estetika sebagai mata kuliah teori di Program Studi Interior FSRD UNTAR. Diharapkan akan berpengaruh pula pada peningkatan hasil belajar mahsiswa sesuai dengan kriteria ketuntasan minimal yang ditetapkan.

\section{METODE}

Pendekatan penelitian yang digunakan dalam penelitian ini adalah pendekatan kualitatif (qualitative research). Bogdan dan Taylor (Moleong, 2007) mendefinisikan metodologi kualitatif sebagai prosedur penelitian yang menghasilkan data deskriptif berupa kata-kata tertulis atau lisan dari orangorang dan perilaku yang dapat diamati.

Lincoln dan Guba (Sayekti Pujosuwarno, 1992) menyebutkan bahwa pendekatan kualitatif dapat juga disebut dengan case study ataupun qualitative, yaitu penelitian yang mendalam dan mendetail tentang segala sesuatu yang berhubungan dengan subjek penelitian. Penelitian kualitatif ini secara spesifik lebih diarahkan pada penggunaan metode studi kasus pada Mata Kuliah Estetika.

Hasil penelitian dianalisis secara deskriptif, yaitu suatu cara analisis atau pengolahan data dengan jalan menyusun secara sistematis dalam bentuk kalimat dan kata-kata, kategorikategori mengenai suatu objek (benda, gejala, variable tertentu), sehingga akhirnya diperoleh kesimpulan umum. Teknik analisis deskriptif kualitatif ini digunakan untuk mengolah data pada hasil temuan proses pembelajaran dan uji coba di Mata Kuliah Estetika. Data dalam penelitian ini terdapat dua jenis data yaitu data primer dan data sekunder. Data primer merupakan data yang diambil langsung dari lapangan berupa hasil kuisioner (a questionnaire survey), dokumentasi tugas mahasiswa dan foto aktifitas kelas yang di ambil pada saat kelas 
berlangsung (participant observation). Data statistik yang digunakan adalah sebagai pelengkap untuk menguji hipotesis dalam penelitian. Teknik analisis data ini dilakukan dengan mengelompokkan informasi dari data kualitatif yang berupa masukan, tanggapan, kritik, dan saran perbaikan yang terdapat pada angket.

\section{HASIL DAN PEMBAHASAN}

\section{A. EMERGING ADULTS DAN ANDRAGOGY}

Emerging adults sebagaimana disampaikan oleh Arnett (2000), adalah periode perkembangan usia remaja akhir menuju awal dua puluhan, dengan fokus kelompok usia 1825 tahun. Kelompok ini memiliki beberapa ciri-ciri khusus sebagai berikut :

- Eksplorasi identitas, yaitu rentang usia yang memiliki kecenderungan untuk menemukan jati dirinya, tentang keinginannya dalam hidup, pendidikan, pekerjaan, serta hubungan percintaannya.

- Ketidakmapanan, bahwa mereka cenderung berpindah-pindah tempat tinggal, berganti kelompok pertemanan, berpindah-pindah pekerjaan.

- Fokus pada diri sendiri, bahwa mereka akan memutuskan apa yang akan dilakukan, ke mana ingin pergi, dengan siapa ingin bersama, sebelum mereka terikat oleh hubungan pernikahan, anak, dan karir.

- Merasa canggung karena berada di pertengahan, karena mereka dituntut untuk bertanggung jawab sementara mereka masih berada dalam tanggung jawab orang tua.

- Berpeluang, bahwa mereka merasa optimis untuk memiliki kehidupan yang lebih baik, berbagai harapan berkembang.

Menurut Arnett Emerging Adults ini bukan remaja maupun dewasa-muda, karena secara teoritis maupun empiris kelompok ini berbeda dari keduanya. Kelompok ini dibedakan melalui kebebasannya yang relatif dalam kehidupan bermasyarakat. Bagi kebanyakan orang, rentang usia ini merupakan periode yang paling penuh semangat dalam kehidupan. Meskipun mahasiswa baru belum sepenuhnya termasuk dalam kelompok usia dewasa, namun mereka tidak dapat lagi diperlakukan sebagai anak-anak. Mereka pun pastinya akan menolak diperlakukan sebagaimana siswa SD, SMP, maupun SMA/SMK sekalipun. Oleh karena itu pengajaran bagi mahasiswa baru termasuk dalam andragogy. Knowles mengajukan konsep andragogi sebagai bentuk 
pengajaran bagi orang dewasa. Andragogi menterjemahkan mahasiswa sebagai :

- Seseorang yang memiliki konsep diri yang independen, yang dapat mengatur bagaimana dirinya akan belajar secara mandiri.

- Seseorang yang telah mengumpulkan sumber pengalaman hidup sebagai sumber daya yang kaya untuk belajar.

- Seseorang yang memiliki kebutuhan belajar, berhubungan erat dengan perubahan peran sosial.

- Seseorang yang lebih berpusat pada permasalahan (problem-centered) dan tertarik pada aplikasi langsung dari pengetahuan.

- Seseorang yang lebih termotivasi oleh faktor internal daripada faktor eksternal.

Dengan demikian mahasiswa baru dalam proses belajar berada pada kondisi yang memiliki semangat yang tinggi dalam hidup, dengan potensi yang kadang belum mereka kenali. Oleh karena itu selama proses belajarmengajar, mahasiswa baru perlu merasa diterima, dihargai dan didukung. Proses pembelajaran mata kuliah Estetika dapat dibuat sedemikian rupa menggunakan strategi pembelajaran bagi orang dewasa, namun tetap memfasilitasi kebutuhan psikologis mahasiswa yang sedang mengalami perubahan menuju dewasa muda.

\section{B. Media Pembelajaran}

Proses pembelajaran merupakan proses komunikasi yang melibatkan tiga komponen pokok, yaitu komponen pengirim pesan (dosen), komponen penerima pesan (siswa), dan komponen pesan itu sendiri yang biasanya berupa materi pelajaran. Dalam proses pembelajaran kemungkinan terjadi kegagalan komunikasi. Untuk menghindari kegagalan komunikasi tersebut, maka dosen dapat menyusun strategi pembelajaran dengan memanfaatkan berbagai media dan sumber belajar. Media pembelajaran adalah alat, metode dan teknik yang digunakan dalam rangka lebih mengefektifkan komunikasi dan interaksi antara guru dan siswa dalam proses pendidikan dan pengajaran di sekolah. Oleh karena itu media pelajaran seyogyanya mampu merangsang pikiran, perasaan, perhatian dan kemampuan atau ketrampilan peserta sehingga dapat mendorong terjadinya proses belajar pada diri peserta didik.

Belajar dengan menggunakan media untuk mencapai tujuan pembelajaran berarti memanfaatkan media untuk menunjang belajar seorang siswa, karena penggunaan 
media bertujuan untuk mempermudah segala kegiatan penyampaian informasi. Kustiyono (2000) mengatakan bahwa media bukan hanya sekedar alat bantu mengajar bagi guru, melainkan merupakan bagaian yang tak terpisahkan dari sistem pengajaran karena media dapat membantu siswa dalam memahami isi pelajaran. Metode pembelajaran tidak akan berjalan dengan maksimal tanpa adanya media pembelajaran. Untuk pemilihan media pembelajaran perlu dipertimbangkan apakah menunjang metode dan membantu mencapai tujuan pembelajaran. Dalam proses belajar mengajar media pembelajaran dapat membangkitkan keinginan, motivasi dan stimulus kegiatan belajar mengajar. Media berfungsi untuk instruksi di mana informasi yang terdapat dalam media harus melibatkan siswa.

Sudjana dan Rivai (1992) mengemukakan manfaat media pembelajaran dalam proses belajar siswa yaitu:

a. Pembelajaran akan lebih menarik perhatian siswa sehingga dapat menumbuhkan motivasi belajar.

b. Bahan pembelajaran akan lebih jelas maknanya sehingga dapat lebih dipahami oleh siswa sehingga memungkinkannya menguasai dan mencapai tujuan pembelajaran. c. Metode mengajar akan lebih bervariasi, tidak semata-mata komunikasi verbal melalui penuturan kata-kata oleh guru, sehingga siswa tidak bosan dan guru tidak kehabisan tenaga, apalagi bila guru mengajar pada setiap jam pelajaran.

d. Siswa dapat lebih banyak melakukan kegiatan belajar sebab tidak hanya mendengarkan uraian guru, tetapi juga aktivitas lain seperti mengamati, melakukan mendemonstrasikan, memamerkan, dll

Penggunaan media pembelajaran dapat mempertinggi kualitas proses dan mafaat belajar mengajar yang pada akhirnya dapat meningkatkan kualitas hasil belajar para siswa. Media pembelajaran menjadi alat bantu bagi tenaga pengajar untuk mengantisipasi tidak berjalannya proses transformasi ilmu seperti yang telah direncanakan. Mata kuliah Estetika selama ini sebagian besar didominasi dengan metode pembelajaran satu arah. Materi yang bersifat teori menyebabkan mata kuliah ini dirasa memerlukan pembaharuan, khususnya dalam pembuatan media pembelajaran, sehingga mahasiswa dapat lebih mudah menangkap materi yang disampaikan dikelas. Penggunaan media pembelajaran dapat menjadi alat bantu 
yang baik, optimalisasi ini akan memberikan dampak yang positif bagi peningkatan prestasi mahasiswa dalam mengikuti mata kuliah tersebut.

\section{Media Pembelajaran Visual}

Perkuliahan melibatkan strategi penyampaian materi melalui beberapa bentuk media, dengan sifat atau karakternya masingmasing. Cara penyampaian materi di kelas dapat berupa verbal, tertulis, maupun verbal. Penyampaian materi secara verbal adalah yang dilakukan secara aktif oleh dosen, sehingga mahasiswa cenderung pasif hanya mendengarkan saja. Sementara untuk melibatkan mahasiswa secara aktif diperlukan kesadaran dosen untuk mengajukan topik diskusi atau secara sederhana memberikan beberapa pertanyaan.

Selain penyampaian materi secara verbal, diperlukan media pendukung untuk membantu mahasiswa dalam pemahaman materi. Media tersebut dapat memuat materi secara tertulis maupun memberikan beberapa contoh berupa visual. Menurut Wina Sanjaya (Wina : 2008) media pembelajaran visual, yaitu media yang hanya dapat dilihat saja, tidak mengandung unsur suara. Yang termasuk ke dalam media ini adalah film slide, foto, tranparansi, lukisan, gambar, dan berbagai bentuk bahan yang dicetak seperti media grafis dan lain sebagainya. Media visual merupakan penyampaian pesan atau informasi secara teknik dan kreatif yang mana menampilkan gambar, grafik serta tata dan letaknya jelas, sehingga penerima pesan dan gagasan dapat diterima sasaran.

Apabila dikaitkan antara media visual dan pembelajaran maka pembelajaran menggunakan media visual tersebut itu akan menarik, efektif dan efesien karena peserta didik dapat melihat perwujudan teks verbal dalam bentuk visual yang lebih mudah dipahami. Media visual merupakan sumber belajar yang berisikan pesan atau materi pelajaran yang dibuat secara menarik dalam bentuk kombinasi gambar, teks, gerak, dan animasi yang disesuaikan dengan usia peserta didik sehingga pembelajaran akan menyenangkan dan tidak menjenuhkan. Dengan demikian media visual dapat menjadi pilihan bagi Mata Kuliah Estetika agar memudahkan dalam penyampaian materi kepada mahasiswa. Mahasiswa akan terbantu dalam memahami materi yang kompleks.

\section{Mata Kuliah Estetika}

Mata Kuliah Estetika adalah mata kuliah yang membahas pengetahuan Estetika dasar yang terdiri dari perkembangan Estetika klasik 
maupun modern hingga tinjauan Estetika dari nilai subyektif dan obyektif. Mata kuliah ini dilaksanakan pada semester satu, yang diambi oleh mahasiswa baru. Tujuan instruksional mata kuliah Estetika adalah penguasaan pengetahuan dasar Estetika terutama yang terkait dengan Desain Interior, sehingga mahasiswa dapat menyusun konsep Estetika secara filosofis maupun empirik untuk diterapkan pada mata kuliah Desain Interior maupun Desain Furnitur.

Materi kuliah petemuan satu sampai dengan enam sebelum Ujian Tengah Semester (UTS) ditekankan pada pengertian dan sejarah Estetika, serta karakter estetis. Mahasiswa diarahkan tidak hanya mengerti hakikat Estetika, namun juga dapat membedakan beberapa gaya desain berdasarkan kualitas visualnya. Sikap objektivitas juga dilatih pada pertemuan ini, sehingga diharapkan di mata kuliah desain (Desain Interior maupun Desain Furnitur) mereka dapat mempertahankan konsep desain masing-masing.

Materi kuliah setelah UTS yaitu pada pertemuan tujuh sampai dua belas, ditujukan untuk mempersiapkan mahasiswa dalam penyusunan konsep Estetika yang akan sangat berguna ketika penulisan laporan tugas akhir desain Interior. Mahasiswa seringkali melupakan esensi konsep Estetika sebuah desain Interior, sehingga yang dituangkan dalam laporan konsep Estetika adalah sebatas elemen dekoratif yang digunakan dalam desain. Pada materi ini diharapkan mahasiswa memiliki kemampuan menjabarkan konsep filosofis (rasionalis) dan konsep empiris (praksis) dan contoh penerapannya dalam desain Interior, sehingga konsep desain yang dituangkan dalam setiap proses desain lebih lengkap dan menyeluruh.

Dengan demikian diperlukan penggunaan media pembelajaran, khususnya visual untuk membantu mahasiswa memahami pengetahuan dasar Estetika, baik dalam bentuk bagan, tabel atau grafis, terutama adalah dalam bentuk contoh penerapannya dalam desain Interior. Pembahasan karya Desain Interior dalam bentuk visual sebagai studi kasus diharapkan dapat membantu proses pembelajaran Estetika, karena mahasiswa akan melihat langsung pengaruh sebuah kualitas visual dalam suasana ruang sebagai bentuk pengalaman estetis bagi pengguna maupun pengamat ruang.

\section{E. Implementasi Media Pembelajaran Visual}

Penggunaan media visual dibagi menjadi dua tahap, yaitu pada 1) Tugas Pertemuan Pertama dan ; 2) Tugas Pertemuan Kedua 


\section{1) Tugas Pertemuan Pertama}

Pada pertemuan pertama materi pembelajaran yang disampaikan adalah mengenai definisi dan makna Estetika. Pertemuan dimulai dengan pertanyaan “Apakah Estetika?". Pada pertemuan awal di kelas mahasiswa diberikan beberapa Visual Interior dengan beberapa gaya desain. Mahasiswa distimulasi untuk mampu 'merasakan' keindahan dan mendeskripsikannya menjadi kata-kata. Visualisasi Interior ruang tidur bergaya Victoria yang terkenal dengan desainnya yang terkesan 'megah dan mewah' menjadi media pembeajaran awal. Kemudian mahasiswa kembali diperlihatkan visual interior ruang keluarga yang bergaya modern yang terkenal dengan slogan 'less is more'.

Pada akhir pertemuan mahasiswa diberikan beberapa materi visual untuk diskusikan bersama kelompoknya dan diberikan tugas mandiri sebagai respon dari materi kuliah hari itu. Tugas visual ini bertujuan agar mahasiswa dapat menghubungkan antara teori dengan tampilan visual gambar. Melalui materi visual ini makna dapat lebih dipahami oleh mahasiswa sehingga memungkinkannya menguasai dan mencapai tujuan pembelajaran. Tugas ini juga disesuaikan dengan tahap awal cara belajar sebagai mahasiswa baru yaitu dengan berpusat pada permasalahan (problem-centered) dan tertarik pada aplikasi langsung dari pengetahuan. Tugas visual yang diberikan bersifat aplikasi langsung materi pemahaman definisi Estetika pada karya Interior. Terdapat dua jenis tugas visual dengan deskripsi berikut:

\section{Tugas 1}

- Carilah sebuah karya Interior/

Bangunan yang paling kalian ingat hingga sekarang.

- Gambarlah Interior/ Bangunan tersebut pada sebuah kertas.

- Tulislah 5 kata yang bisa mendeskripsikan tentang bentuk interior/ bangunan yang kalian gambar Tugas ini bertujuan untuk membangkitkan kepekaan mahasiswa tentang lingkungannya yang kemudian mendekatkan mereka pada keilmuannya (interior). Membuat mahasiswa mampu mengungkapkan rasa di balik sebuah desain. 
Penggunaan Media Pembelajaran Visual pada Mata Kuliah Estetika

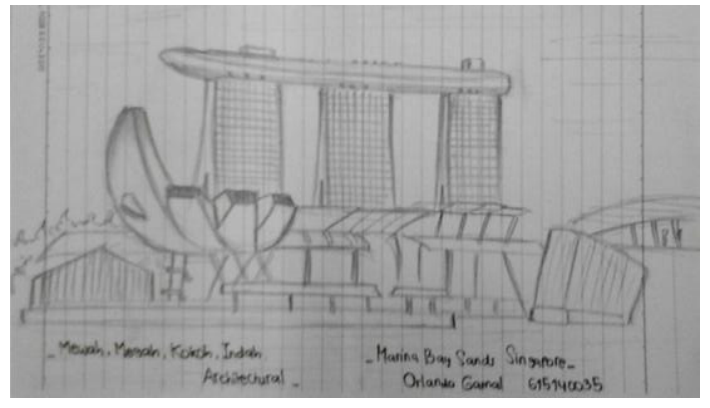

Gambar 1. Hasil sketsa Mahasiswa Marina Bay Sands Sumber : Orlando Gamal, 2 September 2014.

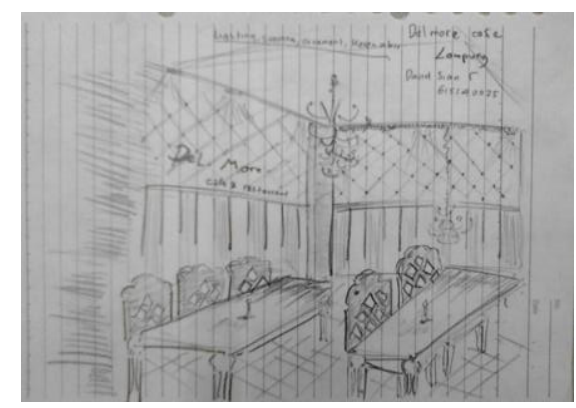

Gambar 2. Sketsa Interior Delmore Cafe, Lampung. Sumber : David Sian, 2 September 2014.

Dari hasil sketsa yang dikumpulkan oleh mahasiswa dapat dilihat bahwa setiap mahasiswa memiliki kemampuan untuk mengekspresikan pengalaman estetisnya dalam bentuk sketsa. Proses refleksi pengalaman yang dituangkan melalui gambar visual membantu mahasiswa dalam memahami pentingnya pengalaman estetis bagi seorang desainer.

\section{Tugas $1(B)$}

- Carilah 1 (satu) gambar Interior yang paling anda sukai. Cetak pada kertas kerja berupa kertas HVS putih berukuran A4 dengan posisi tegak (portrait).

- Bagian bawah gambar dicantumkan sumber gambar (buku/ majalah/ tabloid/ website/ dll).

- Kemudian tulis dengan tangan menggunakan tinta berwarna hitam atau biru, minimal 5 (lima) alasan anda memilih gambar tersebut. Apa yang membuat anda menyukai gambar tersebut?

Tugas ini bertujuan untuk menumbuhkan kepedulian mahasiswa terhadap lingkungan sekitar, termasuk media apapun yang dapat memperkaya wawasan mahasiswa di bidang desain.

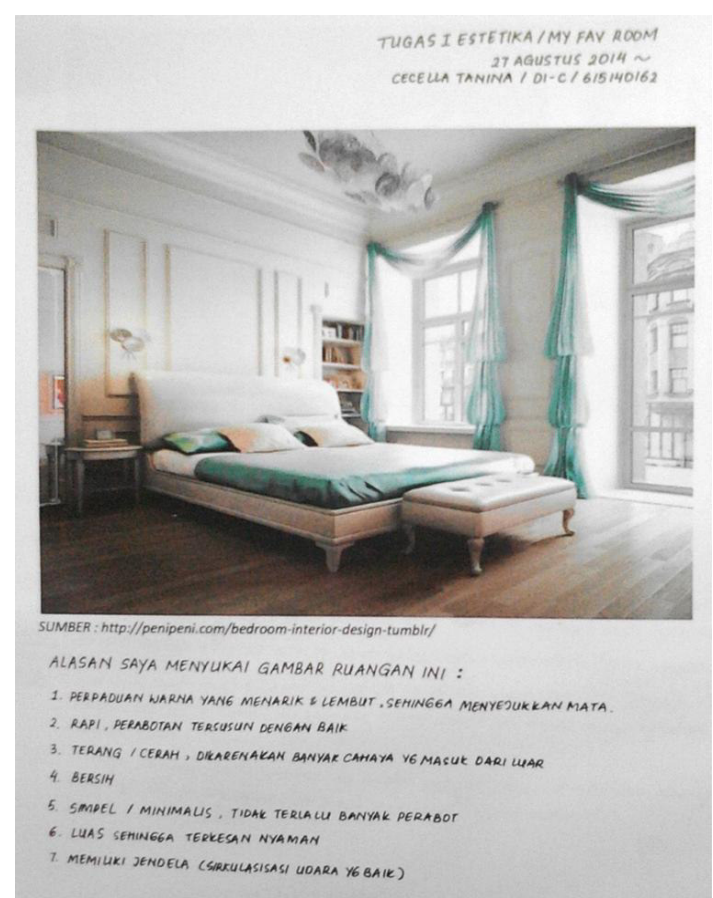

Gambar 3. Contoh Tugas Mahasiswa-Subyektivitas Estetika Sumber : Cecella Tanina (DI-C), 27 Agustus 2014 


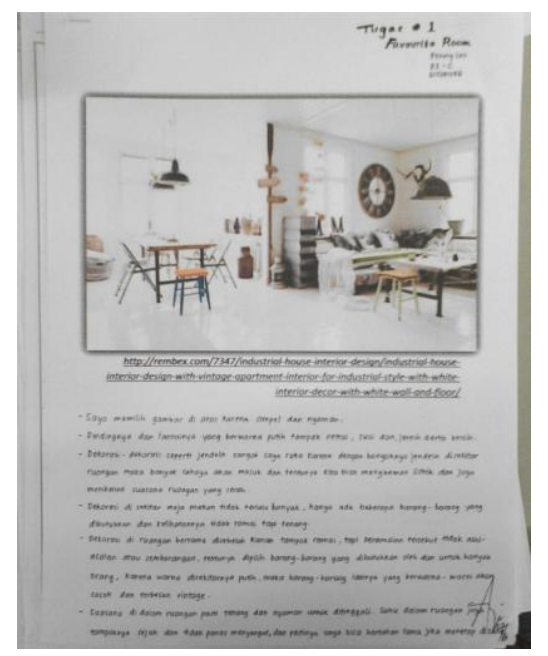

Gambar 4. Contoh Tugas Mahasiswa 2 : Subyektivitas Estetika Sumber : Fenny Leo (DI-C), 27 Agustus 2014

Dari hasil gambar yang dikumpulkan oleh mahasiswa dapat dilihat bahwa setiap mulai menunjukkan keberanian dalam mengekspresikan pengalaman estetisnya. Secara deskriptif mahasiswa mampu mengelompokkan file tersebut berdasarkan klasifikasi tertentu seperti nama ruang, nama furnitur, gaya desain, desainer karya, maupun jenis projek interior.

Hasil penilaian direkapituasi dalam tabel sebagai berikut :

Tabel 1: Hasil Penilaian Tugas 1 (Kelas C dan D)

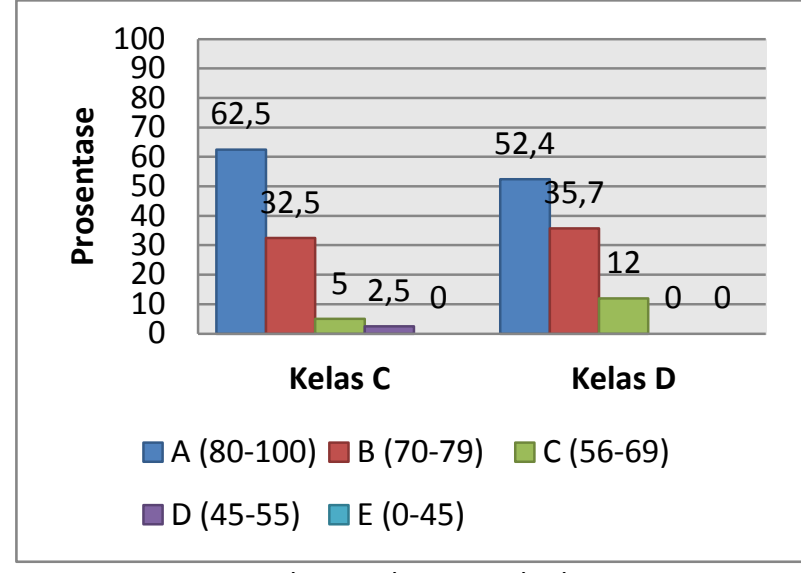

Sumber : Dokumen pribadi

Pada kelas C, prosentase nilai A sebesar $62,5 \%$, nilai B 32,5\%, nilai C 5\%, nilai D 2,5\% dan nilai E 0\%. Sedangkan pada kelas D, prosentase nilai A sebesar $52,4 \%$, nilai B $35,7 \%$, nilai C $12 \%$,nilai D dan E sebesar $0 \%$. Secara umum hasil penilaian seluruh kelas menunjukkan bahwa sebagian besar mahasiswa sudah dapat menjelaskan dengan baik alasan subjektif pemilihan gambar mereka masing-masing. Pemaparan materi perkuliahan yang sebelumnya diberikan dalam bentuk ceramah satu arah, setelah digantikan dalam bentuk studi kasus melalui media pembelajarn visual ternyata memberikan peningkatan dalam hasil pembelajaran.

Keterlibatan mahasiswa dengan perkembangan desain interior baik di dalam maupun di luar negeri, juga menambah pengalaman visual mahasiswa di bidang desain interior terlihat dari cara mereka memilih ragam gambar visual ruang interior 
dalam tugas. Media pembelajaran ini memberi kesempatan kepada siswa untuk dapat lebih banyak melakukan kegiatan belajar. Tidak hanya mendengarkan uraian dalam kelas, namun juga melakukan aktivitas lain seperti mengamati, menganalisa langsung, berdiskusi dan memamerkan hasil tugasnya.

Beberapa mahasiswa yang hasil nilainya dibawah standar, sebagian besar disebabkan karena ketidak tahuannya tentang kosakata desain Interior. Hal ini masih dapat dimaklumi karena sebagai mahasiswa baru mereka masih penyesuaian dalam menjalani pembelajaran orang dewasa. Mahasiswa masih dalam tahap mengumpulkan sumber pengalaman hidup sebagai sumber daya yang kaya untuk belajar. Minimnya kosa kata Desain Interior dapat disebabkan dalam pengalaman hidup sebelumnya, mereka jarang bersinggungan dengan materi tersebut.

\section{2) Tugas Pertemuan Kedua}

Pokok Bahasan pertemuan kedua adalah "Estetika, Seni dan Desain", dengan sub pokok bahasan : Pemahaman Estetik, Elemen Desain. Pada pertemuan ini mahasiswa diajak untuk mencermati kualitas visual pada karya, dengan membuat perincian karakter masingmasing elemen desainnya. Dengan mengenali kualitas visual pada masing-masing elemen desain, mahasiswa belajar untuk memberikan penilaian objektif terhadap karya desain. Sementara tugas pertama sebelumnya hanya merupakan pengenalan bentuk penilaian subjektif terhadap karya.

Pada pertemuan kedua ini, mahasiswa belajar untuk membedakan proses penikmatan estetik yang berdimensi subjektif, dengan proses pemahaman estetik yang berdimensi objektif. Pemahaman terhadap perbedaan kedua proses tersebut akan membantu mahasiswa untuk menerima kritik pengamat desain (dosen pembimbing mata kuliah studio desain) terhadap karya tugas mereka nantinya.

1. Tugas 1

- Baca ulang alasan yang telah anda tulis pada tugas \#1, anda baru saja menuliskan penilaian subjektif terhadap sebuah karya Desain Interior.

- Amatilah setiap elemen desain yang terdapat pada gambar yang anda cantumkan dalam tugas $1(\mathrm{~A})$.

- Sebutkan kualitas visual yang anda temukan pada desain ruang tersebut! Tugas pada ini masih merupakan rangkaian dari tugas sebelumnya, bertujuan agar mahasiswa mampu membuat evaluasi dari pengamatan gambar yang telah mereka 
pilih sendiri di tugas pertama, dan mencari kualitas visual berdasarkan elemen desain masing-masing.

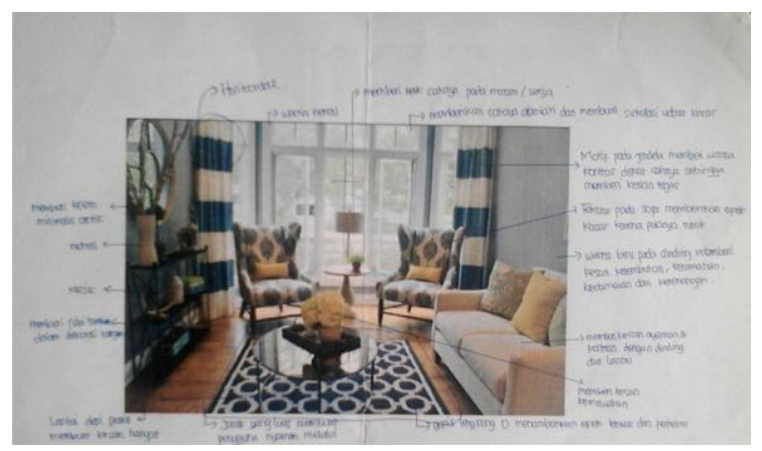

Gambar 5. Contoh Tugas Mahasiswa 1 : Objektivitas Estetika Sumber : Valentina Marcella (DI-C), 3 September 2014

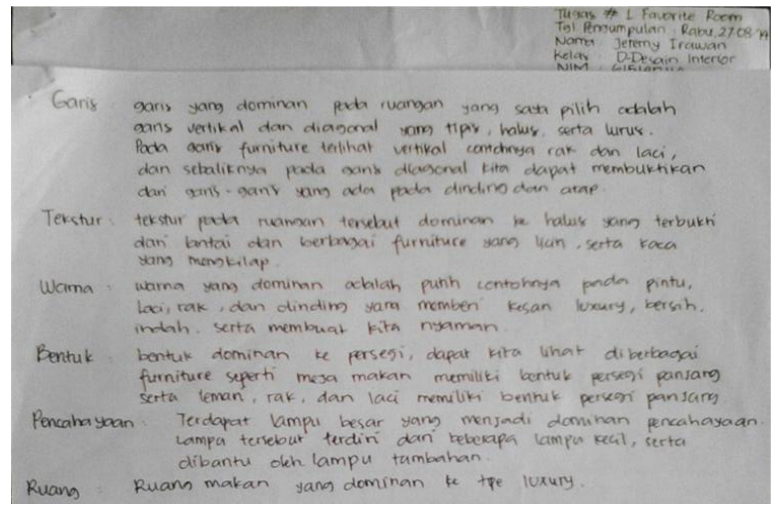

Gambar 6. Contoh Tugas Mahasiswa 2 : Objektivitas Estetika Sumber : Jeremy Irawan (DI-D), 3 September 2014

Dari hasil tugas yang dikumpulkan dapat dilihat bahwa semua mahasiswa mampu mengemukakan alasan objektif mengenai gambar tertentu yang mereka sukai, dari kualitas visual tiap elemen desain. Deskripsi jawaban cukup mendetail. Hal ini menunjukkan bahwa ketertarikan mahasiswa untuk memperdalam sebuah pemahaman atas kualitas estetika cukup tinggi. Pejelasan kualitas diungkapkan secara kongkrit, teknik yang digunakan dalam tugas ini ternyata lebih mengefektifkan komunikasi dan interaksi antara mahasiswa dengan objek yang sedang dipelajari. Media visual membantu mahasiswa memahami kualitas visual dari masing-masing elemen desain pada karya. Hasil penilaian direkapituasi dalam tabel sebagai berikut :

Grafik 4.2. Hasil penilaian tugas 2 (kelas C dan D)

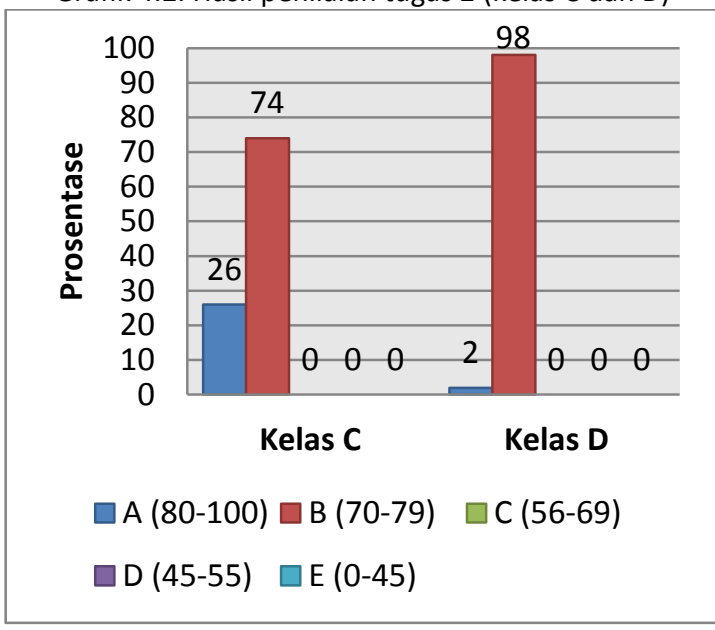

Sumber : Dokumen pribadi

Pada kelas C, prosentase nilai A sebesar 26\%, nilai B 74\%, nilai C 0\%, nilai D $0 \%$ dan nilai E 0\%. Sedangkan pada kelas D, prosentase nilai A sebesar 2\%, nilai B 98\%, nilai C $0 \%$,nilai $D$ dan $E$ sebesar $0 \%$. Secara umum hasil penilaian seluruh kelas menunjukkan bahwa rata-rata sebagian besar mahasiswa sudah mulai mampu memberikan penjelasan objektif dari kualitas visual tiap elemen desain. Walalupun memang 
pencapaian nilai A belum menunjukan prosentase yang tinggi, namun keinginan dalam mengungkapkan pendapat cukup baik.

Berdasarkan hasil tugas kemampuan mahasiswa dalam menjabarkan konsep filosofis (rasionalis) dan konsep empiris (praksis) dan contoh penerapannya dalam desain Interior meningkat, sehingga pemaparan kualitas visual elemen yang merupakan bagian dari pembuatan konsep desain diharapkan dapat dituangkan lebih lengkap dan menyeluruh. Proses ini juga membantu mahasiswa dalam menstimulasi kemampuannya dalam eksplorasi pendapat antara materi berupa objek visual dengan pengalaman internalnya. Sesuai dengan cara belajar sebagai usia dewasa, saat mahasiswa di dekatkan dengan pengalaman internalnya, maka kemampuan dalam mengambil keputusan saat memaparkan pendapat menjadi lebih baik. Sumber pengalaman hidup menjadi sumber daya yang kaya untuk belajar dan memberi dampak pada peningkatan motivasi belajarnya yang terlihat dari hasil penilaian tugas. sumber pengalaman hidup sebagai sumber daya yang kaya untuk belajar.

\section{SIMPULAN}

Penggunaan media visual dalam proses pembelajaran mata kuliah Estetika secara umum dapat membantu mahasiswa dalam memahami prinsip Estetika yang bersifat teoritis. Bagi mahasiswa semester awal yang masih mengalami penyesuaian dalam proses belajar di tingkat universitas, strategi pembelajaran melalui media visual pada mata kuliah Estetika yang diasumsikan sebagai mata kuliah yang sulit dipahami, ternyata membantu proses pembelajaran. Media ini mampu menstimulasi keberanian berekspresi dan kemandirian dalam mengungkapkan pendapat, serta menerangkan bagaimana prinsip-prinsip dalam Estetika yang awalnya masih bersifat abstrak, sehingga dapat lebih dipahami oleh mahasiswa. Hal ini memberi dampak pada meningkatnya penguasaan materi belajar serta tercapainya tujuan pembelajaran. Diharapkan pemahaman tersebut akan membantu mereka dalam mengerjakan tugas Desain Interior, Desain Furnitur, hingga nanti mereka menempuh Tugas Akhir.

\section{UCAPAN TERIMA KASIH}

Ucapan terima kasih dan penghargaan diberikan Lembaga Penelitian dan Publikasi Ilmiah (LPPI) Universitas Tarumanagara yang telah memberikan dukungan dana hibah dan Fakultas Seni Rupa dan Desain Universitas 
Tarumanagara atas dukungan kelancaran

sehingga proses penelitian dapat terlaksana.

\section{DAFTAR PUSTAKA}

Daryanto. 1993. Media Visual untuk Pengajaran Teknik. Bandung : Tarsito

Moleong, Lexy J. 2007. Metodologi Penelitian Kualitatif. Bandung : PT Remaja Rosdakarya Offset.

Sayekti Pujosuwarno. 1992. Penulisan Usulan dan Laporan Penelitian Kualitatif. Yogyakarta: Lemlit IKIP Yogyakarta Arnett, Jeffrey Jensen. 2004. Emerging Adulthood: The Winding Road From the Late Teens Through the Twenties. 1 st edition. New York: Oxford University Press.

Knowles, Malcom S. 1968. "Andragogy, Not Pedagogy". Adult Leadership 29 ; April.

Kustiyono. 2000. Media Pembelajaran. Semarang : Aneka IImu.

Sudjana, N \& Rivai, A. 1992. Media Pembelajaran. Bandung: CV. Sinar Baru.

Sanjaya, Wina. 2008. Strategi Pembelajaran Berorientasi Standar Proses Pendidikan. Jakarta : Kencana. 